\title{
Functional properties and features of clinical application of adipose-derived stem cells in aesthetic medicine and dermatology: a brief review
}

\author{
Ivanishchev V. \\ Chebotarev State Institute of Gerontology of the National Academy of Medical Sciences of Ukraine, Kyiv, Ukraine \\ e-mail: meddoc@i.ua
}

\section{ABSTRACT}

Clinical and experimental data on the application of adipose stem cells in aesthetic medicine and dermatology were analyzed in this brief review. Adipose tissue is a source of safe and easily accessible autologous stem cells with high regenerative potential. The results of numerous experimental and clinical studies prove the prospect of using adipose derived stem cells for the treatment of various skin diseases, as well as in the complex therapy of chrono- and photoaging of the skin.

KEY WORDS: adipose derived stem cells; skin disorders; skin aging; aesthetic medicine

Recent decades have shown a growing scientific and clinical interest in adipose tissue, as the most attractive source of stem cells to use as both a stand-alone method and a part of complex therapy for various pathological conditions in patients [5].

Adipose-derived stem cells (ADSCs) in the necessary amount for therapeutic purposes and aesthetic procedures are easily obtained by lipoaspiration or excision, which is unique advantage over other stem cell sources [11, 38, 53]. In addition, given that adipose tissue has 1 stem cell per 30-1000 cells, but the bone marrow of an adult human has one mesenchymal stem cell per $50.000-1$ million cells, adipose tissue is of much greater interest for the clinical application $[18,32]$.

Modern studies have shown the high efficiency of the use of ADSCs in the treatment of carbohydrate metabolism disorders and limb ischemia. They are successfully used for the repair of bone tissue defects [12]. In addition, adipose-derived stem cells are increasingly used in various programs aimed at prevention skin aging, correcting involutional skin changes and treating many other skin diseases [51].

\section{THE HISTORY OF THE QUESTION}

For the first time, a fragment of adipose tissue was transplanted by German surgeon Gustav Neuber in 1893. He used a fat autograft from the hand to correct the scarring of the orbital cavity after osteomyelitis [36]. Many scientists and physicians of the last century (E. Lexer, L. Peer, etc.) continued to use adipose tissue for scientific and practical purposes to restore the volume of tissues defects [12].

In the 1960s, M. Rodbell and A. James first described the isolation of specific cell population from adipose tissue $[46,47]$. The proposed method included the mincing of an adipose tissue sample, its treatment with collagenase followed by centrifugation. The free-floating fat cells in the supernatant were discarded, and the remaining cells formed a pellet.

M. Rodbell, while studying the cellular composition of this pellet, identified mast cells, macrophages, preadipocytes, pericytes, blood cells, endothelial cells, fibroblasts and fragments of blood vessels in it. He subsequently named the resulting suspension a stromal vascular fraction (SVF) [14]. Later, it was demonstrated that the stromal-vascular fraction is a source of stem/ progenitor cells, similar in morphology and immunophenotype with bonemarrow derived mesenchymal stem cells, as well as capable of differentiation in many directions depending on the culture conditions $[15,29,53]$.

\section{CHARACTERISTICS OF ADIPOSE DERIVED STEM CELLS}

According to the definition of the International Society for Cellular Therapy, «multipotent mesenchymal stromal cells» (MMSCs) include cells that meet the following criteria:

- $\quad$ adhesive to plastic when cultured under standard conditions;

- the expression of specific surface antigens CD90, CD105, CD73, in the absence of expression of hematopoietic markers CD45, CD14, CD34 and histocompatibility antigens HLA-DR;

- $\quad$ the ability to differentiate in vitro into osteoblasts, chondroblasts and adipocytes [12, 21].

MMSCs are a group of cells capable of self-renewing and providing the formation of more committed cells in tissues of mesenchymal origin. In addition, MMSCs can respond to chemoattractive signals and migrate to the damaged target tissues, contributing to the restoration of repair mechanisms, and to maintain hematopoiesis $[10,20]$. 
According to numerous studies, MMSCs in the adult body can be located not only in the bone marrow but also in other tissue niches $[10,38]$. The sources of cells which have the properties of MMSCs are currently the following organs and tissues: skeletal muscles, adipose tissue, synovial fluid, lungs, peripheral and umbilical cord blood, Wharton's umbilical jelly, periodontal ligaments and tooth pulp [35].

ADSCs meet all the characteristics of MMSCs, but they have several advantages. In particular, adipose stem cells are easily obtained in large numbers for medical purposes. They also have reduced immunogenic properties and no ethical controversy regarding their clinical use, unlike cells of fetal origin [17]. ADSCs can be a precursor for chondrocytes, osteocytes, muscle cells, neurons and fibroblasts, as well as keratinocytes under certain conditions. At the same time, adipose derived stem cells do not have additional specific markers, so they are more difficult to identify [17].

It is known that ADSCs have a pronounced secretory activity. They secrete a wide range of proangiogenic factors, the most known are the following cytokines and growth factors: fibroblast growth factor (FGF), hepatocyte growth factor (HGF), vascular endothelial growth factor (VEGF), transforming growth factor beta (TGF- $\beta$ ), granulocyte-macrophage colony-stimulating factor (GM-CSF), nerve growth factor (NGF), placental growth factor (PGF), IL-6, IL-8, IL-17, metallopeptidase inhibitors TIMP-1 and TIMP-2, angiogenin, angiopoietin-1. For example, due to the secretion of VEGF and HGF, adipose-derived stem cells improve blood supply and promote the formation of new collateral vessels in sites of their injections [44]

Thus, the potential for multilinear differentiation into different cell types and the ability to stimulate the angiogenesis makes ADSCs an ideal candidate for the use in regenerative and aesthetic medicine, in particular for the treatment of age-related changes and disorders of the skin [17]

\section{PATHOPHYSIOLOGICAL CHANGES IN THE SKIN DURING AGING}

Skin aging occurs at all levels - molecular, cellular, tissue, and is characterized by the slowing of the cell's functional activity, an imbalance between division and differentiation as well as their death [45]. Atrophic and dystrophic processes in all structural elements of the skin gradually develop [45].

The number and functional activity of fibroblasts in the skin of the elderly ( 80 years and older) is reduced by an average of $35 \%$ relative to the skin of young people (18-29 years). The synthesis of collagen in the skin of the elderly is reduced by an average of $75 \%$ compared to the skin of the young people. As a result, the formation of collagen, elastin, hyaIuronic acid as key components of the dermis decreases, and the skin's elasticity declines [6]. Due to the violation of the intercellular lipid synthesis of the epidermal horny layer, the moisture-holding capacity of the skin decreases and transepidermal water loss increases, it becomes drier, and its turgor decreases [16, 48].

Methods of capillaroscopy and native microscopy revealed the decrease in the number of vertical capillary loops in the papillary layer of the dermis, as well as the decrease in the density of vessels with the age $[25,39]$. According to some studies in the elderly, the number of vascular loops on the forehead is reduced by $40 \%$ [7]. Microcirculatory disorders lead to the disorder of the trophic of sebaceous and sweat glands, which is accompanied by their dysfunction. Deficiency of the vascular plexuses surrounding the hair bulbs can lead to their atrophy, with subsequent decrease in the amount of hair [23, 24].

Resorption of facial skull bones, atrophy and fat redistribution, as well as weakening of the musculoskeletal system occurs with age [4]. Clinically, the external signs of aging on the skin of the elderly are manifested in the form of thinning of the epidermis and dermis, wrinkles, pigment spots, telangiectasias and gravitational ptosis [22, 23].

\section{ADIPOSE-DERIVED STEM CELLS IN SKIN REPAIR}

According to some researchers, the slowdown of cell-dependent regeneration and metabolism is the basis of morphological changes in the epidermis and dermis in the course of chronological aging $[1,2,8]$.
Skin and other soft tissues are restored and renewed due to the presence of regional stem cells. The effect on the tissue of the damaging factor of any genesis (thermal, mechanical, physical) mediates the formation of biological signals that cause asymmetric division and differentiation of stem cells into cells of this tissue and, thereafter, its regeneration. MMSCs from various sources are able to migrate to the site of injury, accumulate there, differentiate and realize the function of replaced damaged cells $[3,9,15]$.

In experimental studies in vitro and in vivo on animal models, it was shown that adipose-derived stem cells have different effects in tissues, including skin. By impact on dermal fibroblasts with growth factors (insulin-like growth factor - IGF, vascular endothelial growth factor - VEGF, platelet-derived growth factor - PDGF), adipose stem cells activate neocollagenesis in the skin [30,32].

Thus, stem cells of adipose tissue, activating the synthetic function of skin cells with fibroblasts and keratinocytes, normalize its repair processes $[26,30,34,38]$. Based on these properties, ADSCs can be widely used for skin regeneration during aging and many other disoreders.

\section{EXPERIMENTAL STUDIES OF ADSCS APPLICATION}

FOR SKIN LESIONS

In the model of nude mice, $\mathrm{H}$. Kim et al. (2009) injected ADSCs subcutaneously in the area of the skin exposed to UV radiation. UV irradiation inhibited the expression of type 1 collagen and matrix metalloproteinkinase-1 (MMP-1). After administration of ADSCs, a significant increase in the expression of type 1 collagen and MMP1 was noted. Histological examination showed a thickening of the dermis due to the significant increase in collagen fibers in the skin of the experimental mice compared to the control group. Enhanced collagen synthesis was mediated by a stimulating effect on dermal fibroblasts and inhibition of collagen degradation [30].

W. Kim et al. (2019) evaluated the efficacy of ADSCs on wound healing rates in injury models in mice using various methods of stem cell administration - intravenous, intramuscular and topical. The treated group had faster healing of the skin wound compared to the control group. The most pronounced dynamics was observed on the 3-4th postoperative days. On the 14th day, in all groups treated with ADSCs, the wounds healed, and in the control groups, the regeneration process remained incomplete. Histological evaluation of the skin samples of the experimental groups showed the completion of the dermis and epidermis formation, adequate vascularization and minimal inflammation compared to the control ones, where the epidermis and dermis were not completely formed, the dermis was less vascularized and residual inflammatory cell infiltrates remained. ADSCs most accelerated the epithelization and the formation of granulation tissue in the period from the $3^{\text {rd }}$ to the $7^{\text {th }}$ postoperative days. It is noteworthy that ADSCs administered intravenously migrated to the area of the wound, and those administered intramuscularly remained at the injection site. ADSCs improved remodeling of skin wounds and these effects were independent of the method of cell administration [27].

Wang et al. have shown the effectiveness of ADSCs in the treatment of hypertrophic scars on rat skin. Cells of the stromal-vascular fraction and stromal-vascular gel were injected into the postoperative scar site. As a result, hypertrophic scars became less visible and softer. Skin thickness was significantly lower in groups using SVF gel and SVF cells than in the control group. The application of SVF gel and SVF cells reduced macrophage infiltration in the dermal layer as well as the expression of interleukin-6 mRNA and monocytic chemoattractive protein-1 (MCP-1). In addition, myofibroblast number and collagen formation were reduced in groups using SVF gel and SVF cells [49]. According to these and other researchers, the positive effect in the correction of scars is due to the secretion of various cytokines and growth factors by the progenitor cells of adipose tissue, including hepatocyte growth factor, IL-10 and adrenomedullin which have antifibrotic properties [24, 29].

According to Zografou et al., the administration of autologous cultured ADSCs improved the survival rate of the skin graft and reduction 
of the necrosis zone in a rat model of diabetes mellitus. Moreover, the density of capillaries, the amount of collagen, the expression of VEGF and TGF- $\beta 3$ significantly increased compared to the control group. These effects (improvement in the survival rate of skin grafts, reduction of the necrosis zone) in diabetic rats are caused by the secretion of growth factors, such as VEGF and TGF- $\beta 3$, the formation of new blood vessels and increased of epithelization [52].

In an in vitro culture, ADSCs increase the proliferative activity of human dermal fibroblasts. The exposure to secretory factors by the paracrine mechanism stimulated the secretion of type 1 collagen and fibronectin. In addition, stimulating effect on the migration of dermal fibroblasts was noted on the model of damage to cell culture in vitro. The subsequent use of ADSCs in wounds in vivo also showed an acceleration of the healing process and marginal epithelization [29].

In vitro experiments have shown that secretion of growth factors by ADSCs increases with decreasing of the oxygen concentration. In particular, subcutaneous administration of a conditioned medium from the human ADSCs culture induced the anagen phase of hair growth and increased hair regeneration in mice. In this case, the culturing medium obtained from the cells cultured in hypoxia induced the anagen phase faster than the culturing medium from the cultures in normoxia. Moreover, such an environment in vitro also enhanced the proliferation of cultured cells of the dermal papilla of the follicle and human epithelial keratinocytes. The levels of insulin like growth factor binding protein 1 and 2 (IGFBP-1 and IGFBP-2), macrophage colony-stimulating factor (M-CSF), plateletderived growth factor receptors beta (PDGF-R $\beta$ ) and VEGF were significantly increased, while the secretion of epidermal growth factor (EGF) was reduced. The authors of this study reasonably suggest that ADSCs promote hair growth through the paracrine mechanism that is enhanced in hypoxia [42].

According to Ji Young Kim (2012), stem cells from human adipose tissue affect proliferation, differentiation, and migration of epidermal melanocytes. Co-culturing significantly enhanced the proliferation and migration of melanocytes relatively to the same indicators in monoculture. This may be due to an increase in the ADSCs production of melanocyte growth factor and basic fibroblast growth factor [31].

Also, co-culturing of ADSCs and melanocytes led to an increase in the number of tyrosinase related protein-2 (Trp-2) positive melanocyte precursors in the culture compared to the melanocyte monoculture. Trp- 1 is known to be expressed only in differentiated melanocytes, while Trp-2 is a marker of their precursors. Moreover, an increase in Trp2 cells may be associated with an increase in the total number of melanocytes in co-culture with ADSCs, because the expression of Trp-2 also has a close relationship with the regulation of cell growth and survival of melanocytes [37]. The obtained data can be used to improve the treatment of skin pigmentation disorders associated with a decrease in the number of melanocytes, for example, vitiligo [31].

\section{THE CLINICAL APPLICATION OF ADSCS IN DERIMATOLOGY}

\section{AND AESTHETIC MEDICINE}

It is believed that the regenerative potential of the skin can be restored in several ways:

- to increase the functional activity of endogenous differentiated cells localized in the skin (for example, fibroblasts, keratinocytes);

- introduce additional stem cells directly into the skin.

Given the pathogenetic mechanisms of skin aging, the activation of endogenous cells seems to be ineffective. It is more appropriate to introduce the pool of exogenous stem cells into the skin in order to improve both the quantity and the functional activity of endogenous progenitor and mature cells.

As a pilot study, Park B. and colleagues injected a lipoaspirate intradermal into the skin of a patient with signs of photoaging. Two months after the last injection, a decrease in the depth of wrinkles, a significant improvement in the texture of the skin and an increase in the thickness of the dermis were noted, which was confirmed by ultrasonographic examination [41].

In the study of M. Amirkhani et al., subcutaneous administration of ADSCs in the area of the nasolabial fold did not show significant visible changes in the skin relief of this area 6 months after the injection. At the same time, according to instrumental examination, the density of the dermis and its thickness significantly increased, and transepidermal water loss decreased [33]. In his clinical practice, G. Rigotti restored soft tissue defects and improved tissue texture using lipofilling method [5].

In the patients with androgenetic alopecia, the injection of autologous fat enriched with the stromal-vascular fraction showed a doubling of hair growth density compared to the patients receiving only injections of autologous fat without SVF. The obtained clinical data suggest that autologous SVF-enriched fat transplants may be a promising approach to the treatment of alopecia in humans [43].

Even intradermal administration of the conditioned medium with adipose derived stem cell growth factors, according to the trichogram, showed a significant increase in the amount of hair in patients diagnosed with alopecia after 6 procedures with an interval of 3-5 weeks [26].

In aesthetic medicine autolipotransplantation, the transplantation of autologous adipose tissue, is also promising. They compensate the volume of lost soft tissues (for example, in the face) and at the same time are as a source of stem cells. Thus, involutive changes in facial fat packs, expressed in their displacement, atrophy, are compensated, and external manifestations of skin aging are harmonized $[5,38]$.

L. Charles-de-Sá et al. performed an injection of autologous fat and ADSCs using CAL technology (cell-assisted lipotransfer) in the preauricular area of 6 patients aged $45-65$ years. The evaluation of the results of skin changes by optical and electron microscopy showed the emergence of new oxalate fibers in the papillary dermis and a decrease of elastosis area. In addition, a three-dimensional modification of the reticular dermis and the formation of a more extensive circulatory network were noted. The skin was more hydrated. It is assumed that the effect of such a combined technique will be slightly higher compared to the use of ADSCs or fat only. In this case, autologous fat acts as a kind of matrix for the functioning of stem cells, creating favorable conditions for their differentiation, and ADSCs trigger the processes of neoangiogenesis for the engraftment of a fat transplant. The authors concluded that the application of ADSCs in combination with autologous fat changes the skin patterns of the subjects towards the state of younger people [20].

Thus, the obtained clinical data allow the widespread use of ADSCs for the treatment of various dermatological diseases, as well as chronoand photoaging of the skin. In this case, the use of adipose-derived stem cells in clinic must be carried out on the basis of clear indications; sufficient clinical experience and taking into account a number of contraindications.

Today, the possible indications for the use of stem cells from adipose tissue are:

- chrono- and photoaging of the skin (starting from the age of $35-40$ years):

- alopecia;

- $\quad$ skin scars;

- $\quad$ chronic skin wounds;

- vitiligo;

- radiation damage to the skin.

It is not recommended to prescribe ADSCs treatment in the following cases:

- pregnancy;

- malignant diseases;

- HIV infection;

- diseases that necessitate the continuous use of antibiotics and hormones [13]. 


\section{CONCLUSION}

The study of the morphological and functional properties of adipose-derived mesenchymal stem cells is a promising and topical direction. The quantity and at the same time the availability of this type of cells demonstrates unique advantages over other sources of stem cells.

Accumulated data of clinical application of stem cells from adipose tissue showed that intradermal injection of ADSCs is safe, activates microcirculation, improves the structure, elasticity of the skin and its appearance.

Adipose tissue as filler can be used to volumize soft tissues lost as a result of diseases, injuries, involutive changes, and can also be used for modeling of the face and body in reconstructive and plastic surgery.

The ability of adipose-derived stem cells to impact the processes of neocollagenesis and angiogenesis is relevant for their application in procedures and programs of aesthetic medicine aimed at improving the skin quality.

\section{REFERENCES}

1. Araviyskaya $E R$. Vozrastnye izmeneniya v derme: novye svedeniya i puti korrektsii s pomoshch'yu sredstv dlya ezhednevnogo ukhoda [Age-related changes in the dermis: new information and ways of correction with the help of daily care products]. Russkiy meditsinskiy zhurnal - Russian medical journal. 2008; 8:574-575. [In Russian]

2. Araviyskaya ER, Sokolovsky EV. Rukovodstvo po dermatokosmetologii [Guide to dermatocosmetology]. SPb: Foliant, 2008. 632 p. [In Russian]

3. Vermel $A E$. Stvolovye kletki: obshchaya kharakteristika i perspektivy primeneniya v klinicheskoy praktike [Stem cells: general characteristics and prospects for use in clinical practice]. Klin med. 2004; 1:5-10. [In Russian]

4. Vorobiev AA, Chigrova NA, Pylaeva IO, Barinova EA. Kosmetologicheskaya anatomiya litsa [Cosmetological anatomy of the face]. SPb: Elbi, 2017. 280 p. [In Russian]

5. Gulikyan GN, Karapetyan GE, Pakhomova RA, Kochetova LV. Effektivnost' autotransplantatsii zhirovoy tkani po dannym literatury [The effectiveness of autologous transplantation of adipose tissue according to the literature]. Sovremennye problemy nauki i obrazovaniya. 2015; 6. http://www.science-education.ru/ru/article/ view?id=23699. [In Russian]

6. Zorina A. Dermal'nye fibroblasty: raznoobrazie fenotipov fiziologicheskikh funktsiy, rol' v starenii kozhi [Dermal fibroblasts: a variety of phenotypes of physiological functions, a role in skin aging]. Esteticheskaya meditsina. 2012; 11(1):15-31. [In Russian]

7. Kalyuzhnaya LD. Starenie kozhi i khronicheskie dermatozy u zhenshchin menopauzal'nogo perioda [Skin aging and chronic dermatoses in menopausal women]. 2006. https://mazg.com.ua/ru-issue-article-10. [In Russian]

8. Kirsanova LV. Izmeneniya kozhi shei u zhenshchin i ikh korrektsiya s primeneniem fraktsionnogo fototermoliza i infrakrasnogo termoliftinga [Changes in the skin of the neck in women and their correction using fractional photothermolysis and infrared thermal lifting]. Dissertatsiya na soiskanie stepeni kandidata mednauk. SPb, 2015. 184 p. [In Russian]

9. Kosmacheva SM, Wolf MV, Potapnev MP. Stvolovye kletki vzroslykh: problemy polucheniya, differentsirovki in vitro, perspektivy klinicheskogo primeneniya [Adult stem cells: problems of obtaining, in vitro differentiation, prospects for clinical use]. Meditsinskie novosti. 2008; 9. http://www.mednovosti.by/journal.aspx?article=3991. [In Russian]

10. Payushina OV. Lokalizatsiya i funktsii mezenkhimnykh stromal'nykh kletok in vivo [Localization and function of mesenchymal stromal cells in vivo]. Zhurnal obshchey biologii - Biology Bulletin Review. 2015; 2:161-172. [In Russian]

11. Petrenko AYu, Ivanov EN, Petrenko YuA. Stvolovye kletki iz zhirovoy tkani [Adipose Stem Cells]. Biotekhnologiya - Biotechnology. 2008; 1(4):39-48. [In Russian]

12. Startseva OI, Melnikov DV, Zakharenko AS, Kirillova KA, Ivanov SI, Pishchikova ED, et al. Mezenkhimal'nye stvolovye kletki zhirovoy tkani: sovremennyy vzgdyad, aktual'nost' i perspektivy primeneniya v plasticheskoy khirurgii [Adipose tissue mesenchymal stem cells: a modern view, relevance and prospects of use in plastic surgery]. Issledovaniya i praktika v meditsine - Research and practical medicine journal. 2016; 3(3):68-75. [In Russian]

13. Takha TV, Nazhmutdinova DK. Kletochnye tekhnologii v kosmetologii i dermatologii [Cell technology in cosmetology and dermatology]. RMZh - RMJ. $2013 ; 22: 1092$. https://www.rmj.ru/articles/dermatologiya/Kletochnye_tehnologii_v_kosmetologii_i_dermatologii/\#ixzz5xcuevHR9. [In Russian]

14. Terskikh WV, Kiseleva EV. Biologicheskie osobennosti i terapevticheskiy potentsial stromal'nykh kletok zhirovoy tkani. Obzor [Biological peculiarities and therapeutic potential of stromal cells of adipose tissue. Review]. Биологические особенности и терапевтический потенциал стромальных клеток жировой ткани. Обзор. Plasticheskaya khirurgiya i kosmetologiya - Plastic Surgery and Cosmetology 2010; 4(6):13-21. [In Russian]

15. Chertkov IL. Differentsirovochnyy potentsial stvolovykh kletok [Stem Cell Differentiation Potential]. Vestnik RAMN - Annals RAMS. 2005; 10:37-44. [In Russian]

16. Hernandez El, Margolin AA, Petrukhina A. Lipidnyy bar'er kozhi i kosmeticheskie sredstva [Skin lipid barrier and cosmetics]. M.: Kosmetika i meditsina, 2005.400 p. [In Russian]

17. Owczarczyk-Saczonek A., Wociór A., Placek W., Maksymowicz W., Wojtkiewicz J. The Use of Adipose-Derived Stem Cells in Selected Skin Diseases (Vitiligo, Alopecia, and Nonhealing Wounds). Stem Cells Int. 2017. URL: https://doi.org/10.1155/2017/4740709.

18. Brown SA, Levi B, Lequex C, Wong VW, Mojallal A, Longaker MT. Basic science review on adipose tissue for clinicians. Plast Reconstr Surg. $2010 ; 126(6): 1409-22$.

19. Caplan Al. Adult mesenchymal stem cells for tissue engineering versus regenerative medicine. J Cell Physiol. 2007; 213(2):341-347.

20. Charles-de-Sá L, Gontijo-de-Amorim NF, Maeda Takiya C, Borojevic R, Benati D, Bernardi P, et al. Antiaging treatment of the facial skin by fat graft and adipose-derived stem cells. Plast Reconstr Surg. 2015; 135(4):999-1009.

21. Dominici M, Le Blanc K, Mueller I, Slaper-Cortenbach I, Marini F, Krause D, et al. Minimal criteria for defining multipotent mesenchymal stromal cells. The International society for cellular therapy position statement. Cytotherapy. 2006; 8(4):315-7.

22. Farage AM, Miller WK, Maibach IH. Textbook of Aging Skin. Springer, 2017. $2222 \mathrm{p}$.

23. Fenske NA, Lober CW. Structural and functional changes of normal aging skin. JAAD. 1986; 15(4):571-585.

24. Jackson WM, Nesti LJ, Tuan RS. Mesenchymal stem cell therapy for attenuation of scar formation during wound healing. Stem Cell Res Ther. 2012; 3(3):20. DOI: 10.1186/scrt111.

25. Kaviani R, Jalili R. Application of Adipose Derived Stem Cells for Treatment of Chronic Wounds. Invest Dermatol Venereol Res. 2016; 2(1):44-51. 
26. Fukuoka $\mathrm{H}$, Suga $\mathrm{H}$. Hair regeneration treatment using adipose-derived stem cell conditioned medium: follow-up with trichograms. Eplasty. 2015; 26(15):10.

27. Hyeonwoo Kim, Mi Ri Hyun, Sang Wha Kim. The Effect of Adipose-Derived Stem Cells on Wound Healing: Comparison of Methods of Application. Stem Cells Int. 2019. https://doi.org/10.1155/2019/2745640.

28. Kelly RI, Pearse R, Bull R, Leveque JL, de Rigal J, Mortimer P. The effects of aging on cutaneous microvasculature. J Am Acad Dermatol. 1995; 33(5):749-756.

29. Kim WS, Park BS, Sung JH, Yang JM, Park SB, Kwak SJ, et al. Wound healing effect of adipose-derived stem cells: a critical role of secretory factors on human dermal fibroblasts. J Dermatol Sci. 2007; 48:15-24.

30. Kim WS, Park BS, Park SH, Kim HK, Sung JH. Antiwrinkle effect of adipose-derived stem cell: activation of dermal fibroblast by secretory factors. J Dermatol Sci. 2009; 53(2):96-10.

31. Lee A, Kim J, Park C, Lee J, Lee C, Do B. Co-culture of Melanocytes with Adipose-derived Stem Cells as a Potential Substitute for Co-culture with Keratinocytes. Acta Derm Venereol. 2012; 92(1):16-2.

32. Lindros B, Suuronen R, Miettinen S. The potential of adipose stem cells in regenerative medicine. Stem Cell Rev. 2011; 7(2):269-91.

33. Amirkhani MA, Shoae-Hassani A, Soleimani M, Hejazi S, Ghalichi L, Nilforoushzadeh MA. Rejuvenation of facial skin and improvement in the dermal architecture by transplantation of autologous stromal vascular fraction: a clinical study. Bioimpacts. 2016; 6(3):149-154.

34. Moon KM, Park YH, Lee JS, Chae YB, Kim MM, Kim DS, et al. The effect of secretory factors of adipose-derived stem cells on human keratinocytes. Int J Mol Sci. 2012; 13:1239-57.

35. Murray IR, West CC, Hardy WR, James AW, Park TS, Nguyen A, et al. Natural history of mesenchymal stem cells, from vessel walls to culture vessels. Cell Mol Life Sci. 2014; 71(8):1353-1374.

36. Neuber G. Uber die Wienderanheilung vollstandig vom Korper getrennter, die ganze Fettschicht enthaltender Hautstucke. Zbl f Chir. 1893; 30:16.

37. Nishioka E, Funasaka $Y$, Kondoh H, Chakraborty AK, Mishima Y, Ichihashi M. Expression of tyrosinase, TRP-1 andTRP-2 in ultraviolet-irradiated human melanomas and melanocytes: TRP-2 protects melanoma cells from ultraviolet B- induced apoptosis. Melanoma Res. 1999; 9:433-443.

38. Naderi N, Combellack E, Griffin M, et al. The regenerative role of adipose-derived stem cells (ADSCs) in plastic and reconstructive surgery. Int Wound J. 2017; 14:112124.

39. Oedayrajsingh-Varma MJ, van Ham SM, Knippenberg M, Helder MN, Klein-Nulend J, Schouten TE, et al. Adipose tissue-derived mesenchymal stem cell yield and growth characteristics are affected by the tissue-harvesting procedure. Cytotherapy. 2006; 8(2):166-77.

40. Park BS, Jang AK, Sung HJ, Park SJ, Kwon HY. Adipose-Derived Stem Cells and Their Secretory Factors as a Promising Therapy for Skin Aging. Dermatol Surg. 2008; 34:1323-1326.

41. Park BS, Jang AK, Sung HJ, Park SJ, Kwon HY. Adipose-Derived Stem Cells and Their Secretory Factors as a Promising Therapy for Skin Aging. Dermatol Surg. 2008; 34:1323-1326.

42. Park BS, Kim WS, Choi JS, Kim HK, Won JH, Ohkubo F, et al. Hair growth stimulated by conditioned medium of adipose-derived stem cells is enhanced by hypoxia: evidence of increased growth factor secretion. Biomed Res. 2010; 31(1):27-34.

43. Perez-Meza D, Ziering C, Sforza $M$, Krishnan G, Ball E, Daniels $E$. Hair follicle growth by stromal vascular fraction-enhanced adipose transplantation in baldness. Stem Cells Cloning. 2017; 10:1-10. DOI: 10.2147/SCCAA.S131431.

44. Rehman J, Traktuev D, Li J, Merfeld-Clauss S, Temm-Grove SG, Bovenkerk SJ, et al. Secretion angiogenic and antiopoptotic factors by human adipose stromal cell. Circulaton. 2004; 109:1292-1298.

45. Rittie Laure, Fisher Gary J. Natural and Sun-Induced Aging of Human Skin. Cold Spring Harb Perspect Med. 2015. D0I: 10.1101/cshperspect.a015370.

46. Rodbell M. Metabolism of isolated fat cells. Effects of hormones on glucose metabolism and lipolysis. Dis Metab.1964; 239(2):375-380.

47. Rodbell $M$, Jones $A B$. Metabolism of isolated fat cells. The similar inhibitory action of phospholipase $\mathrm{c}$ (Clostridium perfringens alpha toxin) and of insulin on lipolysis stimulated by lipolytic hormones and theophylline. J Biol Chem. 1966; 241(1):140-142.

48. Tobin DJ. Introduction to SKIN aging. J Tissue Viability. 2017; 26(1):37- 4

49. Wang Jing, Liao Yunjun, Xia Jing, Wang Zijue, Mo Xiaopei, Feng Jingwei, et al. Mechanical micronization of lipoaspirates for the treatment of hypertrophic scars. Stem Cell Res Ther. 2019. https://stemcellres.biomedcentral.com/articles/10.1186/s13287-019-1140-1.

50. Waller JM, Maibach HI. Age and skin structure and function, a quantitative approach (I): blood flow, pH, thickness, and ultrasound echogenicity. Skin Res Technol. 2005; 11(4):221-35.

51. Zarei F, Abbaszadeh A. Application of Cell Therapy for Anti-Aging Facial Skin. Curr Stem Cell Res Ther. 2019; 14(3):244-248.

52. Zografou A, Papadopoulos 0 , Tsigris $C$, et al. Autologous transplantation of adipose-derived stem cells enhances skin graft survival and wound healing in diabetic rats. Ann Plast Surg. 2013; 71(2):225-232.

53. Zuk PA, Zhu M, Ashjian P. Human adipose tissue is a source of multipotent stem cells. Mol Biol Cell. 2002; 13(12):4279-95.

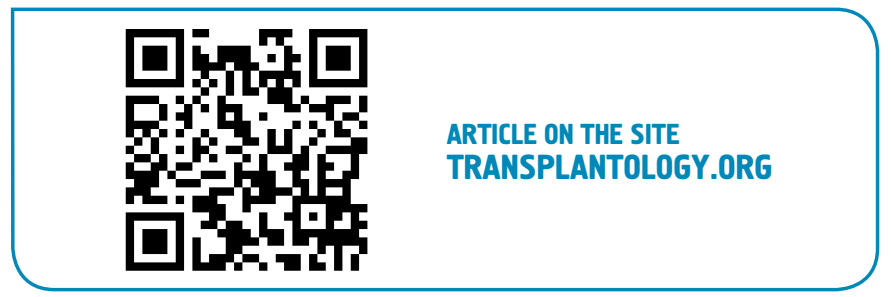

The authors declared no potential conflicts of interest with respect to the research, authorship, and/or publication of this article. 